\title{
ENZIM NITRAT REDUKTASE SEBAGAI INDIKATOR KEBERHASILAN FITOREMEDIASI PADA LUMPUR SIDOARJO
}

\author{
Febi Primavani ${ }^{1)}$ dan Enny Zulaika ${ }^{1 *}$ \\ ${ }^{1)}$ Jurusan Biologi FMIPA - ITS Surabaya 60111 \\ ${ }^{*}$ E-mail: enny@bio.its.ac.id
}

\begin{abstract}
Abstrak
Penelitian bertujuan untuk membuktikan keberhasilan fitoremediasi menggunakan Cassia fistula dengan indikator peningkatan aktivitas enzim nitrat reduktase di daun tanaman. Preparasi lumpur menggunakan penambahan pasir dan pupuk organik 1:1:1, 1:1:2, 1:1:3, 1:1:4. Pengukuran aktivitas nitrat reduktase menggunakan metode spektrofotometri. Substrat enzim terdiri dari buffer pospat $9,8 \mathrm{ml}$ dan $0,2 \mathrm{ml} 0,1 \mathrm{M}$ $\mathrm{NaNO}_{3}$. Preparasi enzim menggunakan substrat $0,2 \mathrm{ml}$ ditambah $2 \mathrm{ml}$ reagen pewarna $\{1 \mathrm{ml} 0,02 \% \mathrm{~N}$ -

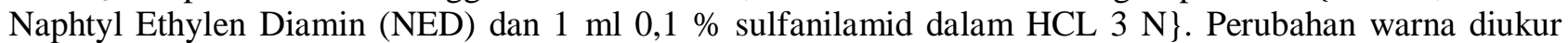
dengan spektrofotometer UV pada panjang gelombang $540 \mathrm{~nm}$. Peningkatan aktivitas enzim nitrat reduktase di daun tanaman $C$. fistula menunjukkan keberhasilan proses fitoremediasi terhadap lumpur Sidoarjo. Peningkatan ANR dari minggu ke 2 sampai 8 menunjukkan korelasi positip $\left(\mathrm{R}^{2}>0,9\right)$. Modifikasi lumpur pada perlakuan V (L:P:PO = 1:1:3) merupakan ANR yang signifikan untuk indikator fitoremediasi, yaitu $0,0369-0,0503 \mu$ molx $10^{-3} / \mathrm{mg} /$ jam dari minggu ke 2 - 8 .
\end{abstract}

Kata kunci: fitoremediasi, lumpur, nitrat-reduktase, pasir, pupuk-organik

\begin{abstract}
This study was to explore Cassia fistula as a potential phytoremediation agent by detecting its enzyme nitrate reductase (ENR) production. The object for phytoremediation was a Sidoarjo mud containing sand and organic fertilizer with ratio 1:1:1, 1:1:2, 1:1:3, 1:1:4, respectively, which were planted with $C$. fistula. The produced enzyme was crudely extracted using $9.8 \mathrm{ml}$ phosphate buffer and $0.2 \mathrm{ml}$ of $0.1 \mathrm{M} \mathrm{NaNO}$. About 0.2 $\mathrm{ml}$ of extracted enzyme was then diluted in $2 \mathrm{ml}$ dye reagent $\{1 \mathrm{ml}$ of $0.02 \% \mathrm{~N}$-Naphtyl Ethylene Diamine (NED) and $1 \mathrm{ml}$ of $0.1 \% \mathrm{HCL}$ sulfanilamid in $3 \mathrm{~N}$ f for detecting its activity using spectrophotometer $540 \mathrm{~nm}$. The results showed that ENR produced by C.fistula was significantly increasing during the incubation time (2 - 8 weeks). C.fistula planted in 1:1:3 (mud:sand:organic fertilizer) gave a highest number of ENR activity around 0,0369-0,0503 $\mu$ molx $10^{-3} /$ week/hour. This result indicated a first hint that $C$.fistula had a futuristic potency for phytoremediation, that need to be investigated further.
\end{abstract}

Keyword:, mud, nitrate-reductase, organic fertilizer, phytoremediation sand 


\section{PENDAHULUAN}

Bencana lumpur Sidoarjo sudah hampir 8 tahun, dan sampai saat ini belum tampak adanya tandatanda luapan tersebut akan berhenti. Peristiwa ini berdampak terhadap hilangnya lahan pertambakan, pertanian, perindustrian dan permukiman di kabupaten Sidoarjo. Berbagai upaya telah dilakukan untuk mengatasi permasalah tersebut tetapi tetapi belum mendapatkan hasil yang maksimal (Wibisono, 2006).

Sifat lumpur Sidoarjo mempunyai salinitas cukup tinggi $\pm 38 \%$, salinitas tersebut lebih besar daripada rata-rata salinitas air laut 30\%. $\mathrm{pH}$ air yang sudah terpisah dari padatan lumpurnya antara 7,3 - 7,7 lebih besar dari $\mathrm{pH}$ air tawar dan hampir sama dengan $\mathrm{pH}$ air laut 8.0 (Siswati et al., 2011).

Lumpur Sidoarjo memiliki butiran dengan diameter 0,004 milimeter, tergolong sebagai larutan koloid (Ashadi, 2006). Berdasarkan uji toksikologis yang dilakukan laboratorium Sucofindo, lumpur Sidoarjo tidak termasuk limbah B3 (Bahan Berbahaya dan Beracun) baik untuk bahan anorganik maupun bahan organiknya (Novianti, 2007).

Bencana sudah terjadi, lumpur jumlahnya sudah berton-ton dan meluas berhektar-hektar. Salah satu alternatif adalah memanfaatkan lumpur supaya berhasil guna yaitu dengan melakukan fitoremediasi untuk memanfaatkan lumpur sebagai media tanamnya. Supaya lumpur dapat dijadikan media tanam, kondisi fisik, kimia maupun biologisnya perlu diperbaiki sehingga layak untuk media tanam dan dapat berfungsi dengan baik. Bahan untuk memperbaiki faktor fisik struktur tanah dapat ditambahkan pasir, sedang untuk memperbaiki faktor kimia dan biologis dapat ditambahkan pupuk organik. Pupuk organik merupakan pupuk yang tersusun dari material makhluk hidup yang mengandung bahan organik (Simanungkalit et al., 2006).

Pupuk organik dapat berbentuk padat atau cair, dengan fungsi dapat memperbaiki sifat fisik, kimia, dan biologi media (Suriadikarta et al.,
2006). Pupuk organik atau biofertilizer murah, berbahan organik ramah lingkungan dan kaya dengan strain mikroorganisme pendegradasi material organik (Muraleedharan et al., 2011).

Fitoremediasi akan berhasil jika tumbuhan yang digunakan adalah tumbuhan yang mempunyai habitat dengan kondisi fisik kimia mirip lumpur Sidoarjo. Cassia fistula merupakan tanaman pesisir dari famili Fabaceae dan dapat tumbuh di daerah yang miskin hara dan salinitas tinggi (Juhaeti et al., 2005), sehingga Cassia fistula dapat dimanfaatkan untuk agensia fitoremediasi lumpur Sidoarjo. Selain itu Cassia fistula dapat dimanfaatkan untuk tanaman hias karena memiliki bunga yang indah bewarna kuning (Wardiyono, 2008).

Indikator keberhasilan fitoremediasi dapat dipantau dari Aktivitas Nitrat Rreduktase (ANR). Nitrat reduktase merupakan enzim utama yang terdapat pada jaringan yang aktif berfotosintesis. Nitrat reduktase memiliki peran yang sangat penting di awal proses sintesis asam amino. Biosintesis nitrat reduktase tergantung pada ketersediaan hara nitrogen dan aktivitasnya dapat diinduksi dengan keberadaan nitrat di daun (Lawlor, 2002). Penelitian bertujuan untuk membuktikan keberhasilan fitoremediasi menggunakan Cassia fistula dengan indikator peningkatan aktivitas enzim nitrat reduktase di daun tanaman.

\section{METODA}

Media tanam yang digunakan adalah lumpur Sidoarjo dari desa Siring, Sidoarjo. Kadar nitrogen, pospor dan kalium (NPK) diukur di Laboratorium BPKI (Balai Penelitian dan Konsultasi Industri) Surabaya. Pupuk organik yang digunakan merek dagang floris ${ }^{\circledR}$. Media tanam adalah lumpur, pasir dan pupuk organik dengan perbandingan:
a. Tanah habitat
b. Lumpur-pasir $=1: 1$
c. Lumpur-pasir-pupuk organik $=1: 1: 1$
d. Lumpur-pasir-pupuk organik $=1: 1: 2$
e. Lumpur-pasir-pupuk organik $=1: 1: 3$
f. Lumpur-pasir-pupuk organik $=1: 1: 4$ 
Masing-masing komposisi media diukur kadar NPK, salinitas dan $\mathrm{pH}$ pada awal dan akhir proses fitoremediasi. Bibit Cassia fistula (umur 7 hari) sebagai agen fitoremediasi dipindahkan ke dalam polybag sesuai perlakuan media. Adaptasi dilakukan selama tujuh hari, jika ada bibit yang mati dilakukan penyulaman dengan bibit yang baru. Pengukuran ANR setelah satu bulan dari masa adaptasi dengan interval waktu dua minggu selama dua bulan berturut-turut.

Pengukuran ANR dilakukan secara in vivo mengacu Zulaika (1985) dan Nur (1986) dalam Alnopri (2004). Daun dipetik pagi hari sebelum jam 8 pagi, ditimbang $300 \mathrm{mg}$ dan dimasukkan dalam botol gelap berisi buffer pospat $10 \mathrm{ml}$ (pH: 7), direndam 24 jam (Alnopri, 2004). Setelah 24 jam, buffer pospat diganti dengan volume 9,8 ml, ditambah 0,2 $\mathrm{ml} \mathrm{0,1} \mathrm{M} \mathrm{NaNO}_{3}$, diinkubasi 3 jam disebut selanjutnya disebut aliquot. Sebanyak 0,2 $\mathrm{ml}$ aliquot dimasukkan kedalam tabung reaksi yang berisi $2 \mathrm{ml}$ reagen pewarna $\{1 \mathrm{ml} 0,02 \%$ N-Naphtyl Ethylen Diamin (NED) dan $1 \mathrm{ml} 0,1 \%$ sulfanilamid dalam HCL $3 \mathrm{~N}$ \}. Didiamkan 15 menit sampai terjadi perubahan warna, ditambah aquades sampai volume $10 \mathrm{ml}$. Absorbansi diukur dengan spektrofoto meter UV pada panjang gelombang $540 \mathrm{~nm}$. Sebagai larutan blangko digunakan $2 \mathrm{ml}$ reagen pewarna.

Data ANR di uji dengan Analisis of Varians (Anova) untuk mengetahui perbedaan ANR. Uji beda nyata menggunakan Least Significant Difference (LSD) dengan taraf kepercayaan $\alpha$ : 5\% (Walpole, 2003).

\section{HASIL DAN PEMBAHASAN}

Semakin banyak penambahan pupuk organik, kadar nitrogen, pospor dan kalium (NPK) semakin tinggi (Gambar 1). Di akhir perlakuan fitoremediasi, salinitas dan $\mathrm{pH}$ di semua komposisi media tanam mempunyai besran yang hampir sama. Salinitas sama dengan salinitas air tawar dan $\mathrm{pH}$ mendekati netral. Secara rinci dapat dilihat di Tabel 1. Penambahan pasir dan pupuk organik dapat menurunkan salinitas dan $\mathrm{pH}$ lumpur. Salinitas mendekati dan hampir sama dengan salinitas air tawar dan $\mathrm{pH}$ mendekati $\mathrm{pH}$ netral. Hal ini mengindikasikan bahwa penambahan pasir dan pupuk organik dapat memperbaiki sifat kimia lumpur sebagai habitat untuk fitoremediasi.

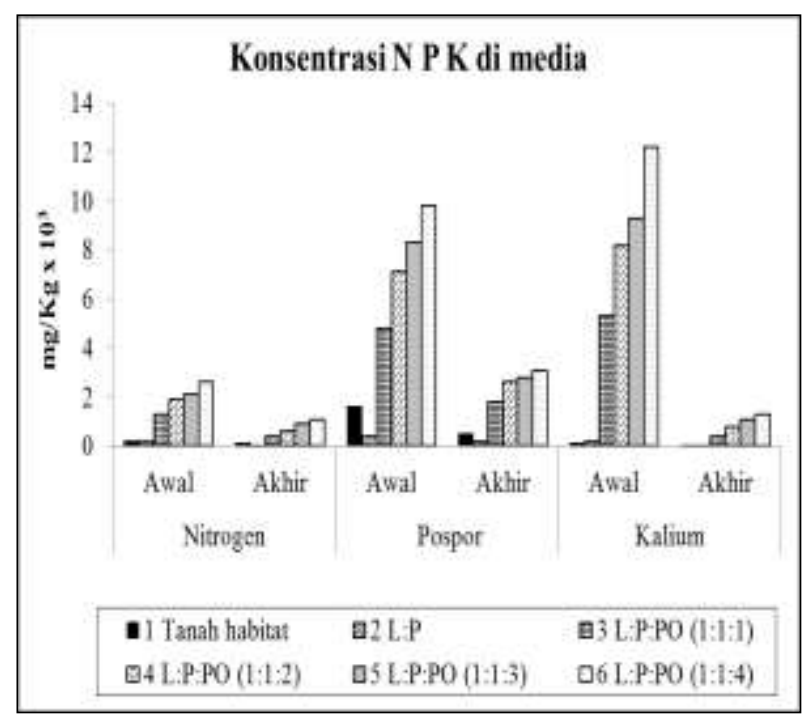

Gambar 1. Kadar NPK di media

Tabel 1. Salinitas dan $\mathrm{pH}$ lumpur modifikasi di akhir pengamatan

\begin{tabular}{lcc}
\hline \multicolumn{1}{r}{ Perlakuan } & Salinitas (\%) & $\mathrm{pH}$ \\
\hline Tanah habitat & 0.01 & 6,82 \\
L:P & 0.03 & 6,55 \\
L:P:PO (1:1:1) & 0.02 & 6,61 \\
L:P:PO (1:1:2) & 0.02 & 6,68 \\
L:P:PO (1:1:3) & 0.01 & 6,74 \\
L:P:PO (1:1:4) & 0.01 & 6,78 \\
\hline
\end{tabular}

Keterangan: L:lumpur, P:pasir; PO: pupuk organik

Secara fisiologis, toleransi tanaman terhadap salintas dan $\mathrm{pH}$ merupakan fisiologi yang kompleks, tanaman halofit akan lebih toleran terhadap salinitas tinggi dibandingkan tanaman bukan halofit (Chinnusamy et al., 2004). Salinitas dan keasaman media tanam dapat menghambat pertumbuhan dan produktivitas tanaman (Mane et al., 2010)

Kadar NPK yang terbesar terdapat pada komposisi media L:P:PO = 1:1:4. yaitu 2600 $\mathrm{mg} / \mathrm{kg}$ nitrogen, $9800 \mathrm{mg} / \mathrm{kg}$ pospor dan 12.200 $\mathrm{mg} / \mathrm{kg}$ kalium. Diakhir perlakuan fitoremediasi, 
Tabel 2. Kadar NPK tersedia di awal dan akhir perlakuan fitoremediasi

\begin{tabular}{ccccccccccc}
\hline \multirow{2}{*}{ PERLAKUAN } & \multicolumn{3}{c}{ Nitrogen (mg/kg) } & \multicolumn{3}{c}{ Pospor (mg/kg) } & \multicolumn{3}{c}{ Kalium (mg/kg) } \\
\cline { 3 - 10 } & & Awal & Akhir & $\%$ & Awal & Akhir & $\%$ & Awal & Akhir & $\%$ \\
\hline 1 & Tanah habitat & 200 & 100 & 50 & 1600 & 500 & 69 & 100 & 0 & 100 \\
2 & L:P (1:1) & 200 & 100 & 50 & 400 & 200 & 50 & 200 & 100 & 50 \\
3 & L:P:PO (1:1:1) & 1300 & 400 & 69 & 4800 & 1800 & 63 & 5300 & 400 & 92 \\
4 & L:P:PO (1:1:2) & 1900 & 600 & 68 & 7100 & 2600 & 63 & 8200 & 800 & 90 \\
5 & L:P:PO (1:1:3) & 2100 & 900 & 57 & 8300 & 2800 & 66 & 9300 & 1100 & 88 \\
6 & L:P:PO (1:1:4) & 2600 & 1100 & 58 & 9800 & 3100 & 68 & 12200 & 1300 & 89 \\
\hline
\end{tabular}

Keterangan: L: lumpur, P: pasir; PO: pupuk organic

kadar NPK mengalami penurunan $50-100 \%$ (Tabel 2). Fakta ini merupakan indikasi bahwa unsur NPK di lumpur modifikasi dengan pasir dan pupuk organik dapat dimanfaatkan agen fitoremediasi Cassia fistula untuk memenuhi kebutuhan selama pertumbuhan dan viabilitas hidupnya sampai 8 minggu awal kehidupan.

Komponen mineral dalam tanah terdiri dari campuran partikel yang dengan ukuran yang berbeda. Media bertekstur pasir sangat mudah diolah, memiliki aerasi dan drainase yang baik tetapi kemampuan menyimpan air sangat rendah. Penambahan pupuk organik pada media lumpur pasir, dapat memperbaiki sifat fisikakimia lumpur, yaitu membuat agregasi antara lumpur, pasir dan pupuk organik. Dapat memperbaiki permeabilitas terhadap air, dan meningkatkan kapasitas tukar kation sehingga dapat meningkatkan pengikatan ion unsur hara yang tersedia dan mudah diabsorpsi oleh akar tanaman (Hardjowigeno, 2003).

ANR daun Cassia fistula pada semua perlakuan fitoremediasi meningkat seiring bertambahnya waktu. ANR yang tertinggi terdapat pada media tanah habitat (sebagai kontrol), diikuti L:P:PO=1:1:4 dan terendah pada perlakuan lumpur-pasir tanpa pupuk organik (Gambar 2 dan 3). Nitrat reduktase merupakan enzim intraseluler yang mereduksi ion nitrat menjadi ion nitrit. Keberadaan enzim nitrat reduktase dapat digunakan sebagai parameter untuk melihat jalur metabolisme awal pembentukan asam amino dan pertumbuhan tanaman (Garbin
\& Dillenburg, 2008). ANR dan distribusi enzim NR dipengaruhi oleh beberapa faktor, antara lain umur tanaman, umur daun dan varietasnya sehingga seiring meningkatnya ANR maka laju metabolisme tanaman akan meningkat pula (Suhesti et al., 2006).

Kebanyakan tanaman mengambil nitrogen dari tanah dalam bentuk ion ammonium $\left(\mathrm{NH}_{4}{ }^{+}\right)$atau ion nitrat $\left(\mathrm{NO}_{3}{ }^{-}\right)$, nitrat merupakan ion yang paling banyak diserap oleh tanaman (Sirait, 2006). Sebagian besar nitrat yang terserap dialokasikan pada daun, sehingga mengakibatkan meningkatnya ANR di daun (Iqbal, 2008).

Hal ini ditunjukkan pula oleh hasil berat kering dan luas daun, perlakuan tanah taman dan pasirpupuk organik memberikan hasil yang tinggi. Menurut Suhesti et al. (2006) terdapat korelasi antara ANR dengan produktivitas tanaman, jika produktivitas tanaman menurun maka ANR juga menurun.

ANR adalah enzim yang mengkatalisis nitrat $\left(\mathrm{NO}_{3}{ }^{-}\right)$menjadi nitrit $\left(\mathrm{NO}_{2}^{-}\right)$, ketersediaan nitrat di media akan mempengaruhi laju ANR (Rahmawati et al., 2009). Tanaman menyerap nitrat sesuai kebutuhannya, pemberian pupuk organik yang semakin banyak diasumsikan kadar nitrat tersedia juga semakin banyak. Akibatnya enzim nitrat reduktase bekerjanya dapat maksimal karena subtrat nitrat tersedia semakin banyak. 


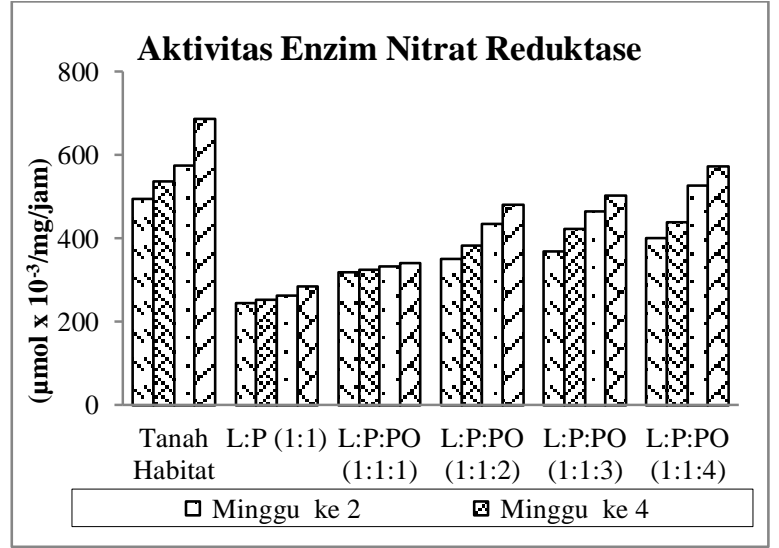

Gambar 1. ANR daun Cassia fistula pada komposis media yang berbeda.

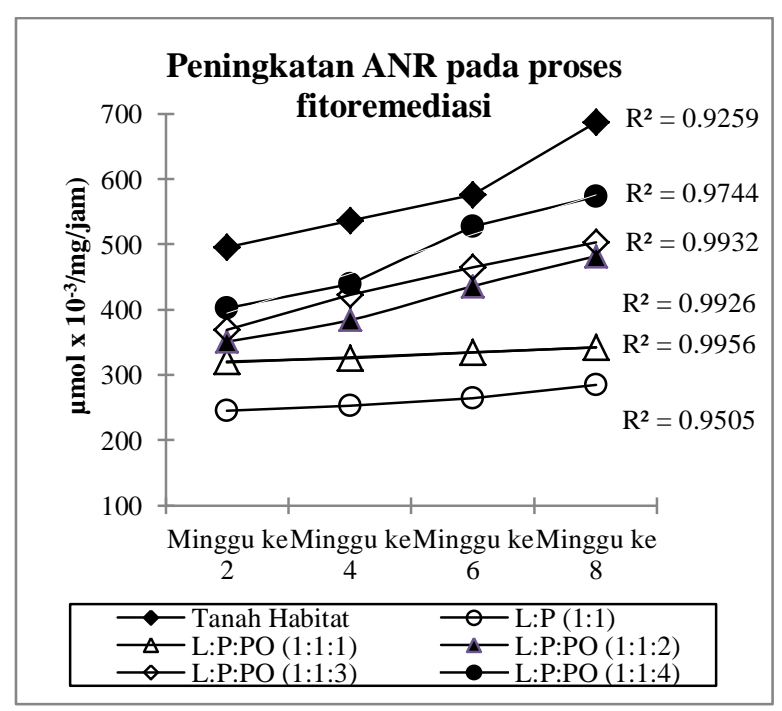

Gambar 2. Peningkatan aktivitas enzim nitrat reduktase sebagai indikator viabilitas Cassia fistula untuk agensia fitoremediasi.

Berdasarkan uji Anova, penambahan pupuk organik tidak meberikan pengaruh signifikan pada ANR daun $C$. fistula antara perlakuan II dan III, perlakuan IV dan V serta perlakuan I dan VI, tetapi berbeda nyata antara perlakuan II dan III dengan IV dan V dengan I dan VI (Tabel 3). Lumpur memiliki butiran sangat halus dengan ukuran $0,0039 \mathrm{~mm}$, lumpur juga merupakan koloid yaitu suatu bahan mineral yang sulit dipisahkan antara air dan padatannya. Ion nitrat merupakan ion yang mudah bergerak sehingga cepat larut, penambahan pasir menyebabkan adanya porositas yang semakin besar, nuitrat tidak teradsorbsi oleh media lumpur-pasir dan ion nitrat mudah tercuci dan hilang dari media (Muklis, 2003).

Pada perlakuan IV-V penambahan pupuk organik tidak memberikan pengaruh yang berbeda nyata antara dua perlakuan tersebut. Penambahan pupuk organik perbandingan 2 dan 3 mempunyai pengaruh yang sama. Pada perlakuan $\mathrm{V}$, penambahan pupuk organik dengan perbandingan 4 memberikan pengaruh yang berbeda nyata dari perlakuan I sampai IV, artinya penambahan pupuk organik dapat memberikan peningkatan nitrat tersedia dan aktivitas nitrat reduktase menjadi lebih maksimal. ANR pada media kontrol (tanah habitat) adalah yang tertinggi dibanding perlakuan yang lain, padahal kadar nitrogen pada media kontrol relatif sama dengan media lumpur-pasir, bedanya kadar pospornya lebih tinggi dibandingkan media lumpur-pasir (Tabel 3) Keberadaan pospor pada media akan membantu memperbaiki perakaran dan membuat tanaman tahan terhadap kekeringan (Wijaya, 2008). Media dengan kandungan pospor yang memadai akan memperbaiki perakaran, meningkatkan penyerapan ion nitrat, dan ANR yang dihasilkan akan lebih tinggi. Perlakuan $\mathrm{V}$ dengan penambahan pupuk organik empat kali dari lumpur-pasir dapat menyamai agregat media dari habitat aslinya, pemberian pupuk organik dapat memperbaiki $\mathrm{pH}$ tanah menjadi netral.

Media dengan $\mathrm{pH}$ netral akan menyebabkan peneyarapan unsur hara menjadi optimal (Cazetta et al., 2004), walau pada media kontrol, unsur hara terukur rendah tetapi tanaman lebih mudah beradaptasi pada habitat aslinya dibandingkan habitat yang telah dimodifikasi.

\section{KESIMPULAN}

Modifikasi lumpur Sidoarjo dengan pasir dan pupuk organik sebagai media tanam dapat dimanfaatkan sebagai alternatif rehabilitasi bencana lumpur Sidoarjo. Tanam Cassia fistula dapat dijadikan agen fitoremediasi dengan media lumpur yang telah dimodifikasi. Viabilitas $C$. fistula sebagai agen fitoremediasi ditunjukkan dengan peningkatan ANR yang merupakan ekspresi akar mampu mengabsorsi nitrat di media. Peningkatan ANR dari minggu ke 2 sampai 8, 
semua perlakuan menunjukkan korelasi positip dengan $\mathrm{R}^{2}>0,9$. Modifikasi lumpur pada perlakuan $\mathrm{V} \quad(\mathrm{L}: \mathrm{P}: \mathrm{PO}=1: 1: 3)$ merupakan ANR yang signifikan yaitu 0,0369 $\mu$ molx $10^{-3} / \mathrm{mg} / \mathrm{jam}$ di minggu ke 2 sampai $0,0503 \mu$ molx $10^{-3} / \mathrm{mg} / \mathrm{jam}$ di minggu ke 8 .

\section{DAFTAR PUSTAKA}

Alnopri (2004). Modifikasi rancangan dalil untuk mendapatkan kopi arabika unggul berrdasarkan aktivitas nitrta reduktase. Jurnal Akta agrosia, 7 (2). 3-8

Ashadi, R.S. 2006. WALHI Jatim Tolak Pembuangan Lumpur Lapindo. URL: http://www.walhijatim-

issue.blogspot.com.

Diunduh April 2014.

Cazetta, J. O dan Villela, L. C. V. 2004. Nitrate Reductase Activity In Leaves And Stems Of Tanner Grass (Brachiaria radicans Napper). Science Agricultural. 61 (6). $640-648$.

Chinnusamy, V., J. Andre, and J. K. Zhu. 2005. Understanding and improving salt tolerance in plants. Crop Sci. 45:437-448.

Garbin, M.L. and L.C. Dillenburg. 2008. Effect of different nitrogen sources on growth, chlorophyll concentration, nntrate reductase activity and carbon and nitrogen distribution on Araucaria angustifolia. Braz. J. Plant Physiol. 20 (4): 295-303

Hardjowigeno, S. 2003. Ilmu Tanah. Aka demika Pressindo. Jakarta.

Iqbal, A. 2008. Potensi Kompos dan Pupuk Kandang untuk Produksi Padi Organik di Tanah Inceptisol. Jurnal Akta Agrosia. 11 (1). 13-18

Juhaeti, T., Syarif, F. dan Hidayati, N. 2005. Inventarisasi tumbuhan potensial untuk fitoremediasi lahan dan air terdegradasi penambangan emas. Biodiversitas. 6 (1): 3133

Lawlor, D.W. 2002. Limitation to photo synthesis in water-stress leaves: stomata vs metabolism and role of ATP. Annals of Botany. 89: 871885.

Mane, A. V., B. A. Karadge and J. S. Samant, 2010. Salinity induced changes in photo synthetic pigments and polyphenols of Cymbopogon nardus (L.) Rendle. J. Chem. Pharm. Res. 2:338-347.

Muraleedharan, H., Seshadri, S. and Perumal, K. 2010. Biofertilizer (Phosphobacteria), Shri AMM Murugappa Chettiar Research Centre. Taramani, Chennai-600113.

Novianti, D. 2007. Penelitian awal pemanfaatan lumpur Porong Kabupaten Sidoarjo untuk komponen bangunan. Jurnal Permukiman 2 (2). Balitbang PU. Bandung

Rahmawati, D.S., R. Rahmaniah., R. Aviana., dan M. N. Rachmad. 2009. Pemafaatan Hara Air Laut untuk Memenuhi Kebutuhan Tanaman Sebagai Alternatif Solusi Kelangkaan Pupuk. Jurusan Kimia Uni versitas Negeri Malang.

Simanungkalit, R.D.M., D.A. Suryadikarta., R. Saraswati., D. Setyorini., dan W. Hartatik. 2006. Pupuk Organik dan Pupuk Hayati. Balai Besar Litbang Sumberdaya Lahan Pertanian Badan Penelitian dan Pengembangan Pertanian.

Sirait, J. 2006. Dinamika Nitrogen dan Produksi Rumput Benggala (Panicum maximum cv Riversdale) Pada Tiga Taraf Naungan dan Pemupukan. Seminar Nasional Teknologi Peternakan dan Veteriner

Siswati, N.D., Dwi P, Y., \& Ika L, C. 2011. Utilization of Sidoarjo mud as the raw material of making portland cement. Articles Bali International Seminar on Science and Technology, 22-23. 
Suriadikarta, D. A. dan Simanungkalit, R.D.M. 2006. Pupuk Organik dan Pupuk Hayati. Jawa Barat: Balai Besar Penelitian dan Pengembangan Sumberdaya Lahan Pertanian. ISBN 978-979-9474-57-5.

Walpole, R.E. 2003. Ilmu Peluang dan Statistika untuk Insinyut dan Ilmuwan edisi ke-4. Bandung: ITB.

Wardiyono, 2008. Detail Cassia fistula. <URL:http://www.kehati.com> diakses pada 25 Agustus 2012.

Wibisono, Y. 2006. Tragedi lumpur Lapindo: akar masalah dan solusinya. http://agorsiloku.wordpress.com/2006/10/ 11/tragedi-lumpur-lapindo/ diunduh tanggal 12 Maret 2013.

Wijaya, K.A. 2008. Nutrisi Tanaman.Prestasi Pustaka Publisher. Jakarta.

Zulaika, E. 1985 . Respon aktivitas nitrat reduktase daun Cocos nucifera yang dihilangkan endosspermnya terhadap pemupukan NPK. Fakultas Biologi UGM Yogyakarta. 